\title{
Rozmieszczenie i geneza wspólczesnych osuwisk nizinnych w strefie bezpośredniego oddziaływania rzeki na przykładzie zbocza Doliny Dolnej Wisły między Morskiem a Wiągiem
}

\author{
Distribution and origin of contemporary lowland landslides in the area of the direct river \\ impact, on the example of section of Lower Vistula Valley between Morsk and Wiąg
}

\author{
Sebastian Tyszkowski \\ Instytut Geografii i Przestrzennego Zagospodarowania, Polska Akademia Nauk, Toruń, sebtys@wp.pl
}

\begin{abstract}
Zarys treści: $\mathrm{W}$ artykule poruszono problematykę rozwoju współczesnych ruchów masowych w strefie krawędziowej doliny rzecznej. Obszar badań zlokalizowany jest w obrębie Doliny Dolnej Wisły, w okolicach Świecia, i wyróżnia się spośród terenów sąsiednich bezpośrednim oddziaływaniem rzeki na zbocze doliny. Osuwiska stanowią istotny proces kształtowania stoku, zajmując 30\% jego powierzchni. Przeanalizowano czynniki bierne i aktywne wpływające na rozwój osuwisk. Pod uwagę wzięto m.in. aktywność wód gruntowych oraz czynnik erozyjnego oddziaływania rzeki.
\end{abstract}

Słowa kluczowe: osuwiska, czynniki aktywizujące ruchy masowe, kartowanie osuwiskowe, Dolina Dolnej Wisły

\begin{abstract}
The article raises the issue of development of current mass movements in the escarpment zone of river valley. The study area is located in Lower Vistula Valley near Świecie. The area is distinguished from its neighboring areas by the direct influence of the river on a slope, resulting inter alia to the development of landslides. They constitute an important process of shaping this slopes, occupying 30 percent of its surface. The paper presents an analysis of passive and active factors affecting the development of local landslides. The analysis has taken into consideration the factor of groundwater, geological settings and river erosion impacts.
\end{abstract}

Key words: landslides, activating factors of mass movements, landslides mapping, Lower Vistula Valley

\section{Wstęp}

Głównym procesem współcześnie modelującym zbocza dolinne na Niżu Polskim jest spłukiwanie (Florek i in. 2008). Istnieją jednak obszary, na których stoki kształtowane są również przez bardziej spektakularne procesy, do których należą osuwiska. Przykładem jest Dolina Dolnej Wisły, a szczególnie jej odcinek w okolicy Świecia. Należy on do nielicznych miejsc w obrębie Doliny Dolnej Wisły, w których rzeka dociera bezpośrednio do zbocza doliny, a równina zalewowa praktycznie nie występuje (ryc. 1). Takie położenie warunkuje szereg procesów geomorfologicznych, z których najważniejszym jest erozyjne podcinanie stoków, sprawiające że teren ten jest predysponowany do występowania osuwisk.
W południowej Polsce, na obszarach górskich i pogórskich, osuwiska występują znacznie częściej i zajmują do $30-40 \%$ powierzchni stoków, przez co dominują w rzeźbie terenu (Starkel 1960, Kotarba 1986, Ziętara 1988, Alexandrowicz, Margielewski 2010). Problematyka ich rozwoju na obszarach nizinnych była najczęściej poruszana przy okazji analizy form rozwijających się w otoczeniu sztucznych zbiorników wodnych, wśród których zdecydowanie najciekawszym i najlepiej zbadanym obiektem jest Zbiornik Włocławski (Banach 1977, 1994, 1998, Kühn 1981, Glazer 1998, Wysokiński 1998, Banach i in. 2013). Formy ruchów masowych dokumentowane były również w sąsiedztwie mniejszych zbiorników, takich jak Zbiornik Pakoski (Grobelska 2006) czy zbiornik Jeziorsko (Kaczmarek 2010a, b). 
Celem pracy jest przedstawienie rozmieszczenia i funkcjonowania osuwisk w strefie krawędziowej doliny, w bezpośrednim sąsiedztwie koryta Wisły.

\section{Obszar badań}

Rejon badań położony jest w obrębie strefy krawędziowej Wysoczyzny Świeckiej i Doliny Dolnej Wisły. Wyznaczony tam obszar testowy, w którym przeprowadzono badania geomorfologiczne, ma długość około 3,5 km i rozciąga się na wschód od Świecia, między miejscowościami Morsk i Wiąg (ryc. 1). Długość stoków wynosi przeciętnie 150-200 m. Jest to jeden z nielicznych fragmentów w obrębie Doliny Dolnej Wisły, w którym rzeka podcina zbocze doliny przyległej do wysoczyzny. Miejscami, u podnóża zbocza, wykształcił się niewielki, inicjalny fragment równiny zalewowej o szerokości 10-20 m, zalewany w okresie wezbrań. Wysoczyzna morenowa położona jest tu na wysokości blisko $90 \mathrm{~m}$ n.p.m., natomiast dno doliny Wisły ma rzędne 20,2-20,9 m n.p.m. Nachylenie zboczy wynosi zwykle od 15 do $35^{\circ}$, a w skrajnych przypadkach przekracza $45^{\circ}$.

W literaturze szeroko rozważane są koncepcje przedczwartorzędowego założenia Doliny Dolnej Wisły, zwłaszcza na obszarze Powiśla. Dominuje pogląd, że Dolina Dolnej Wisły nawiązuje do starszych kopalnych obniżeń, rozwiniętych w osadach kredy, paleogenu i neogenu (Galon 1934, Mojski 1982). Osady starsze niż paleogeńskie znajdują się na badanym obszarze na rzędnych około 90 m p.p.m. Na miocenie zalegają formacje piaszczyste powstałe we wczesnym vistulianie (Wysota 2002). $\mathrm{Na}$ terenie badań stwierdzono trzy warstwy glin lodowcowych rozdzielone osadami fluwioglacjalnymi i glacilimnicznymi (Tyszkowski 2012a). Warstwy tych osadów w rejonie badań zalegają horyzontalnie, nie stwierdzono również śladów zaburzeń glacitektonicznych.

Wody gruntowe pojawiają się na stokach sporadycznie $\mathrm{w}$ miejscach przecięcia jednej $\mathrm{z}$ dwóch warstw wodonośnych (Tyszkowski 2012b). Pierwsza z nich, o małych zasobach, znajduje się w obrębie piasków drobnych i mułków na rzędnych 70-75 m n.p.m., na kontakcie ze stropem glin lub iłów i jest izolowana przez co najmniej 4-metrowy pokład zwartych glin. Aktywność wód gruntowych w obrębie tej warstwy wyrażana jest epizodycznie w postaci niewielkich wysięków i podmokłości w górnej części stoku.

Drugi poziom wód gruntowych jest hydraulicznie połączony z wodami Wisły i rozwinięty w piaskach i żwirach na rzędnych $0-25 \mathrm{~m}$ n.p.m. Obszar zasilania tego poziomu wodonośnego jest znacznie rozprzestrzeniony w głąb wysoczyzny i ma bardzo duże zasoby wodne. Równoczesne duże zasilanie i drenujący charakter strefy krawędziowej skutkują wzrostem spadku hydraulicznego (I) wód drugiego poziomu wodonośnego, wynoszącego tu $\mathrm{I}=0,005\left(5 \mathrm{~m} \mathrm{~km}^{-1}\right)$ (Chmielowska 1997, Zambrzycka 2002). Wody pochodzące $\mathrm{z}$ tej warstwy w postaci źródeł i podmokłości można spotkać na powierzchni terenu sporadycznie, jedynie w dolnej części stoku na rzędnych 21-23 m n.p.m.

Opady atmosferyczne w obrębie analizowanego odcinka doliny Wisły należą do niewielkich w skali kraju i wynoszą od 490 do $550 \mathrm{~mm}$ rocznie (Wójcik, Marciniak 1993). Stany wody w rejonie dolnej Wisły są w większości konsekwencją warunków hydrometeorologicznych w górnej części dorzecza, co szczególnie związane jest z ekstremalnymi zdarzeniami wezbraniowymi (Churski 1993). Najwyższe stany wody $z$ lat $1971-1990$ przypadają na kwiecień (Babiński, Grześ 1995).

Współcześnie procesy erozyjne rzeki zostały częściowo osłabione poprzez przeprowadzoną w XIX i XX w.

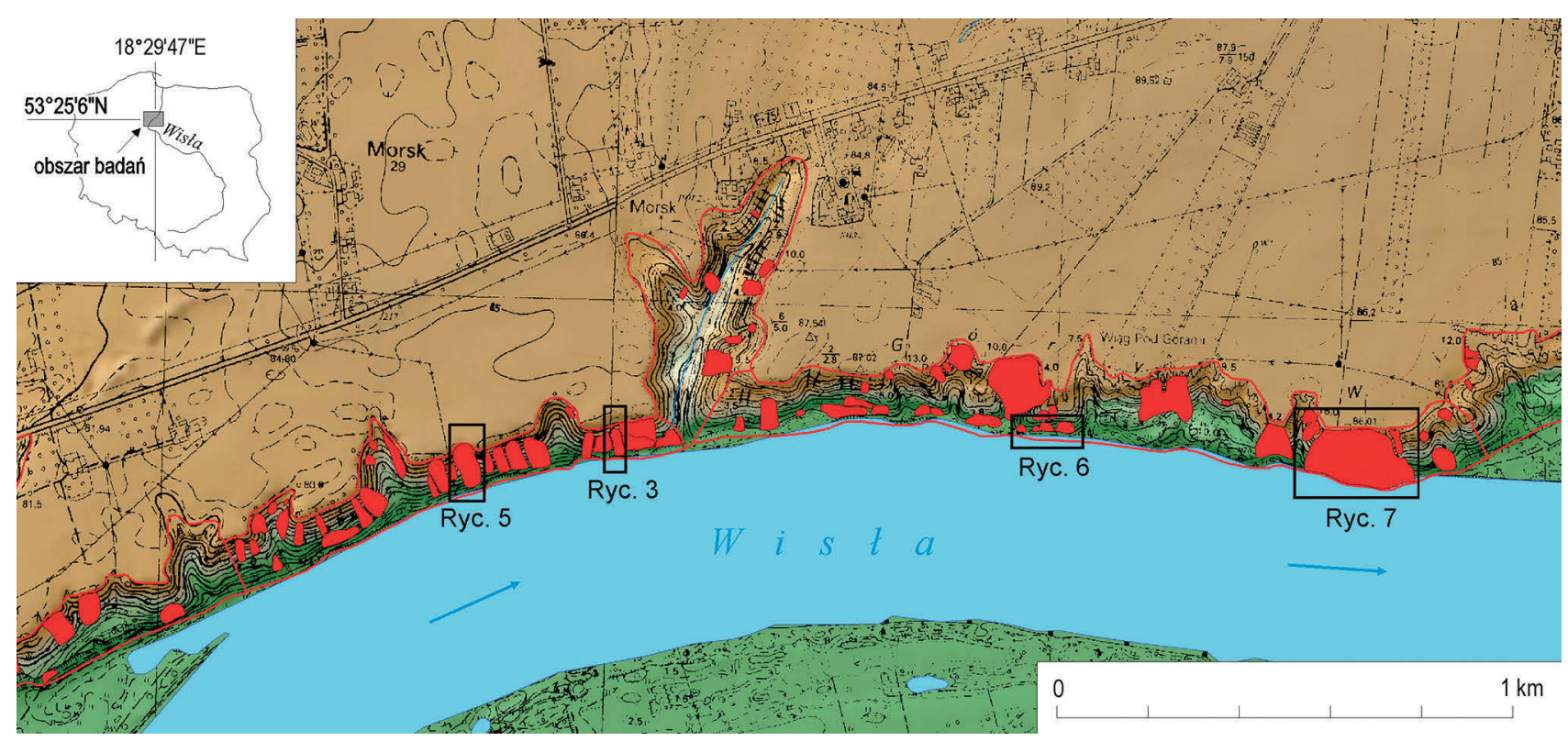

Ryc. 1. Położenie obszaru badań. Osuwiska (kolor czerwony) w obrębie strefy krawędziowej

Fig. 1. Location of study area. Landslides (marked in red) located on the escarpment zone 
regulację Wisły. Na podstawie analizy map topograficznych w skali 1:25 000 z początku XX w., oraz szczegółowych opracowań dokumentujących prace hydrotechniczne na wymienionym odcinku zidentyfikowano 20 ostróg o długości od 30 do $70 \mathrm{~m}$, rozmieszczonych średnio co 200-300 m.

\section{Metody badań}

Podstawą prowadzonych badań było szczegółowe kartowanie geomorfologiczne i geologiczne. Rozpoznanie budowy geologicznej osuwisk przeprowadzono za pomocą sond ręcznych i mechanicznych. Ponadto w wybranych osuwiskach wykonywano pomiary parametrów geotechnicznych gruntów sypkich sondą dynamiczną SD-10 (DPL) i sondą obrotową VT w gruntach spoistych (PNB-04452:2002), co pozwoliło na określenie miąższości koluwiów i głębokości powierzchni poślizgu.

Wiek osuwisk oceniano głównie na podstawie zmian morfologicznych, które zaszły w ich obrębie, takich jak obecność świeżych obrywów, szczelin, pozostałości po ich zaniku. Ponadto w miejscach, gdzie było to możliwe, weryfikowano obecność osuwisk na archiwalnych zdjęciach lotniczych z lat 1961, 1972, 1987, 1996 i 2005 w skalach od 1:12 000 do 1:26 000, korzystając $\mathrm{z}$ trybu obserwacji stereoskopowej oraz poprzez poddanie ich kalibracji przestrzennej w środowisku oprogramowania GIS.

Dodatkowym kryterium określenia momentu wystąpienia ruchów masowych było oszacowanie wieku pokrycia roślinnego występującego w obrębie osuwisk na podstawie obserwacji terenowych oraz analizy materiałów fotogrametrycznych.

Wykorzystując wytyczne stosowane w instrukcji do kartowania osuwisk Systemu Osłony Przeciwosuwiskowej SOPO (Grabowski i in. 2008), za osuwiska aktywne uznano te, które są w ciągłym ruchu lub których objawy aktywności występowały w ostatnich 5 latach. W przypadku osuwisk aktywnych okresowo przyjęto ramy czasowe ostatniej stwierdzonej bądź szacowanej aktywności w okresie 5-50 lat. Osuwiskami nieaktywnymi, ustabilizowanymi, nazwano formy, w których obrębie nie obserwowano i nie udokumentowano objawów aktywności co najmniej w ciągu ostatnich 50 lat.

W celu ilościowego określenia stopnia przekształcenia stoków przez ruchy masowe wykorzystano wskaźnik osuwiskowości powierzchniowej $\mathrm{O}_{\mathrm{p}}$ - stosunek łącznej powierzchni osuwisk na danym terenie do powierzchni terenu - oraz gęstość osuwisk G - stosunek liczby osuwisk na danym terenie do powierzchni tego terenu (Bober 1984, Zabuski i in. 1999).

\section{Stan wiedzy}

Do końca XX w. stan wiedzy na temat ruchów masowych na badanym obszarze był bardzo pobieżny, aczkolwiek osuwiska w dolinie Wisły były wzmiankowane już w pracy Galona (1934), który zwrócił uwagę na obecność w rejonie Świecia teras osuwiskowych.

W latach 1968-1970 okolice Świecia zostały poddane kartowaniu w ramach ogólnopolskiego projektu Państwowego Instytutu Geologicznego, którego wynikiem było opracowanie mapy osuwisk województw w skali 1:100 000 (Kühn, Miłoszewska 1971). Wówczas to w obrębie strefy krawędziowej o długości $8 \mathrm{~km}$, między Świeciem a Sartowicami, zidentyfikowano 11 osuwisk o powierzchni od $400 \mathrm{~m}^{2}$ do 2,5 ha, łącznie zajmujących 8,7 ha. Kolejnym opracowaniem, w którym poruszono wspomnianą tematykę, były wyniki kartowania osuwisk wykonane w latach 2003-2004 (Rejestracja 2004). Różnią się one w niewielkim stopniu od rejestracji z lat 70., wskazując na odcinku między Świeciem a Sartowicami jedynie 4 osuwiska.

W ostatnich latach wybrane problemy związane z obecnością osuwisk w tej części Doliny Dolnej Wisły przedstawione zostały w pracach Habla i in. (2008), Kordowskiego i Tyszkowskiego (2008) oraz Tyszkowskiego (2008, 2009, 2012c). Szczególną uwagę poświęcono analizie rozwoju osuwiska w Wiągu (Tyszkowski 2012a).

\section{Wyniki}

Badania geomorfologiczne na odcinku stoku doliny Wisły pomiędzy miejscowościami Morsk i Wiąg pozwoliły wyróżnić 58 osuwisk, których łączna powierzchnia stanowi ponad 11 ha. Mediana powierzchni poszczególnych osuwisk wynosi niewiele poniżej $1000 \mathrm{~m}^{2}$ (ryc. 2). $\mathrm{Na}$ wielkość średniej powierzchni osuwisk $\left(1930 \mathrm{~m}^{2}\right)$ mają wpływ nieliczne, ale rozległe formy przekraczające $4000 \mathrm{~m}^{2}$. Długość osuwisk wynosi średnio $45 \mathrm{~m}$. W dużej mierze wartość ta jest warunkowana morfologią i niewielką długością stoku (średnio $40 \mathrm{~m}$ ), na którym formy te powstają.

$\mathrm{W}$ analizie pionowego rozmieszczenia osuwisk na stoku zaznacza się duży udział form rozwiniętych w jego górnej części - niemal 50\%, przy wyraźnie mniejszej liczbie form powstałych w części dolnej - poniżej 20\%.

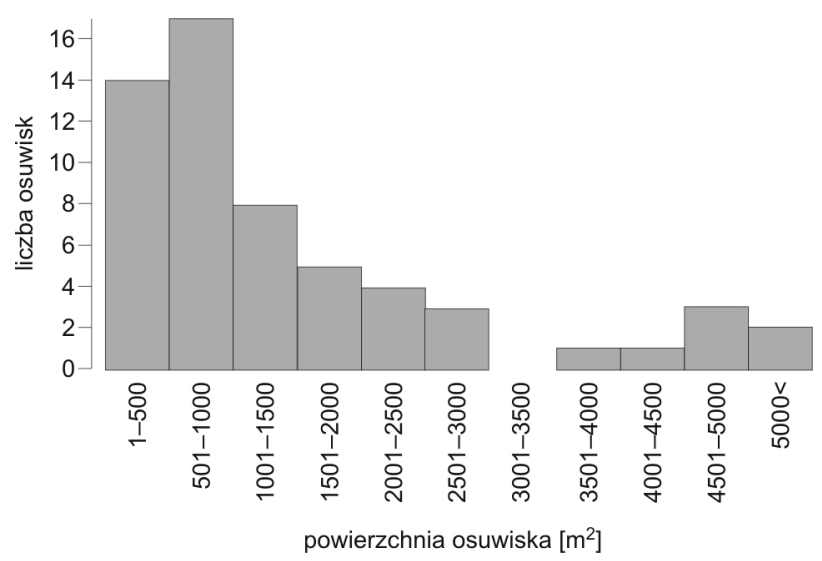

Ryc. 2. Rozkład powierzchni osuwisk

Fig. 2. Distribution of landslides area 

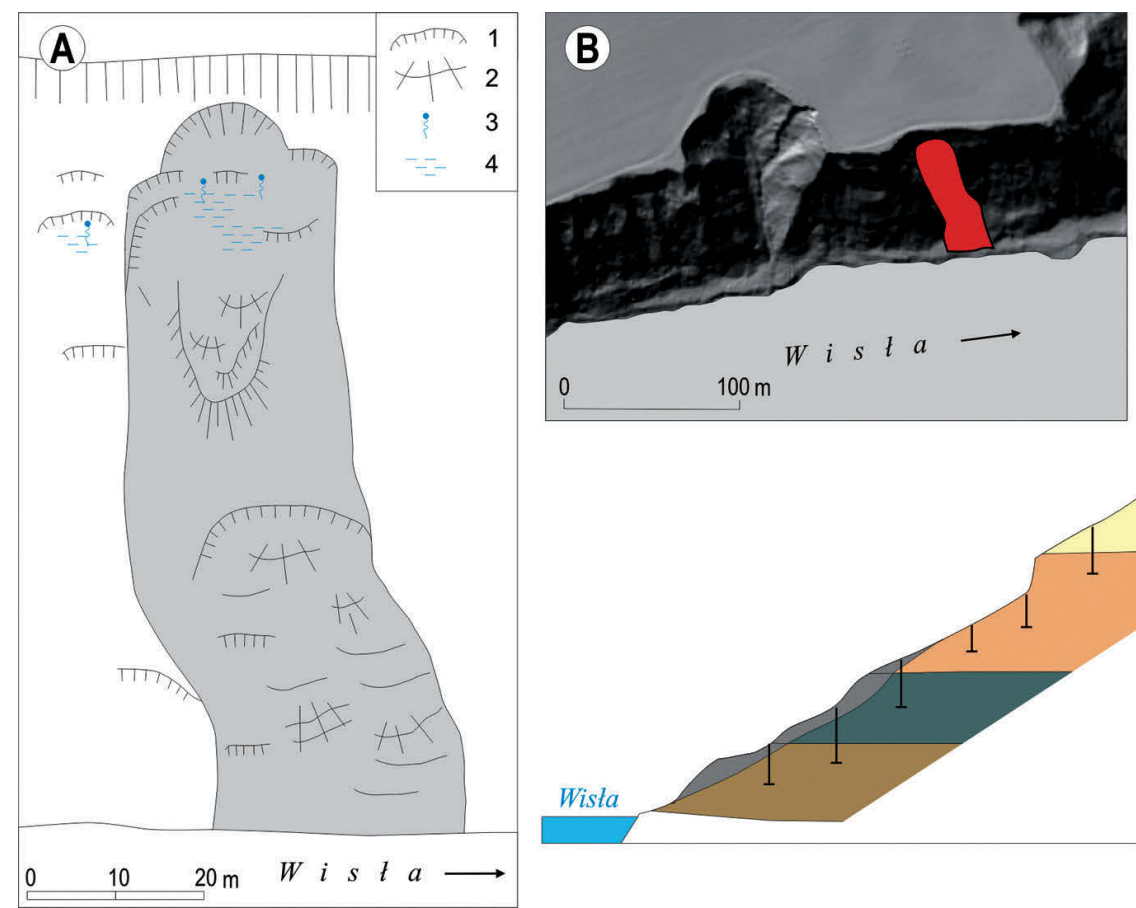

(C)

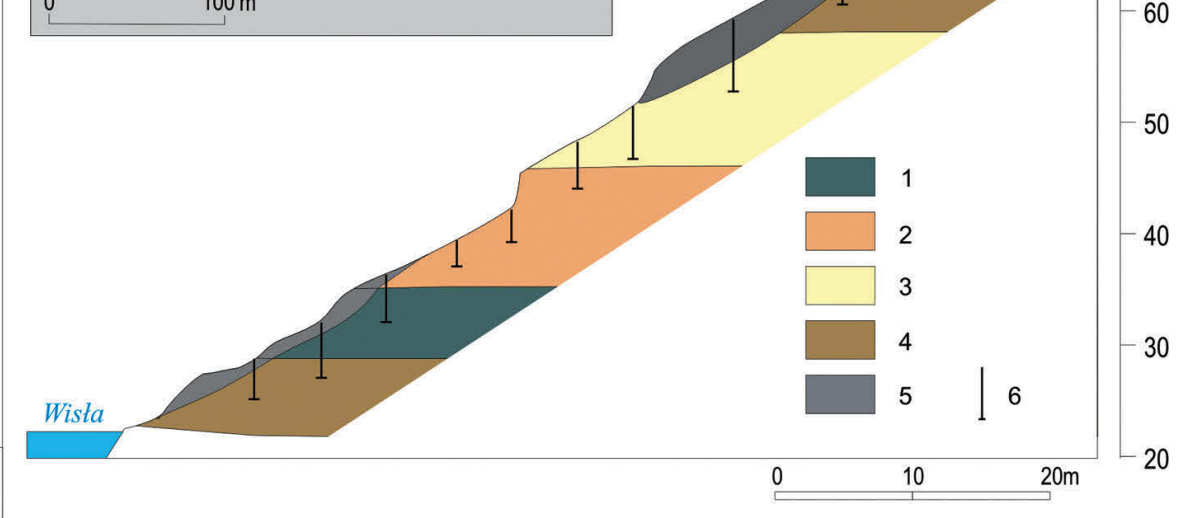

Ryc. 3. Osuwisko w Morsku, rozwinięte w górnej części stoku

A - szkic morfologii osuwiska (1 - skarpy, 2 - jęzory koluwialne, 3 - źródła, 4 - młaki), B - położenie osuwiska w obrębie strefy krawędziowej, C przekrój geologiczny wzdłuż osi podłużnej osuwiska (1 - ił, 2 - mułek, 3 - piasek, 4 - glina, 5 - koluwia, 6 - wiercenia)

Fig. 3. Landslide in Morsk, developed in the upper part of the slope

A - morphology of the landslide (1 - scarps, 2 - colluvial tongues, 3 - springs, 4 - swamps), B - landslide location on the escarpment zone, C - geological cross-section along the longitudinal axis of the landslide ( 1 - clay, 2 - silt, 3 - sand, 4 - till, 5 - colluviums, 6 - boreholes)

Osuwiska rozwinięte na całej długości stoku, między jego górnym a dolnym załomem, stanowią niewiele ponad $25 \%$ udokumentowanych form.

Dominującą formą przemieszczeń gruntu na prezentowanym obszarze testowym są płytkie zsuwy rotacyjne (wg klasyfikacji WP/WLI 1993), stanowiące ponad 70\% osuwisk, a zaraz po nich spełzywanie, które również często występuje jako drugorzędny przejaw ruchu materiału poddanego zsuwom.
Ocena miąższości koluwiów jest w wielu przypadkach utrudniona, gdyż na stokach objętych osuwiskami zalegają dodatkowo utwory pochodzące $\mathrm{z}$ pojedynczych obrywów z korony zbocza oraz deluwia.

Osuwiska na odcinku stoku doliny Wisły pomiędzy miejscowościami Morsk i Wiąg cechują się dużą aktywnością. W ciągu ostatnich 50 lat powstało bądź uległo reaktywacji $74 \%$ form, w tym $28 \%$ w ostatnich 5 latach. O dużej roli osuwisk w kształtowaniu rzeźby zbocza doli-
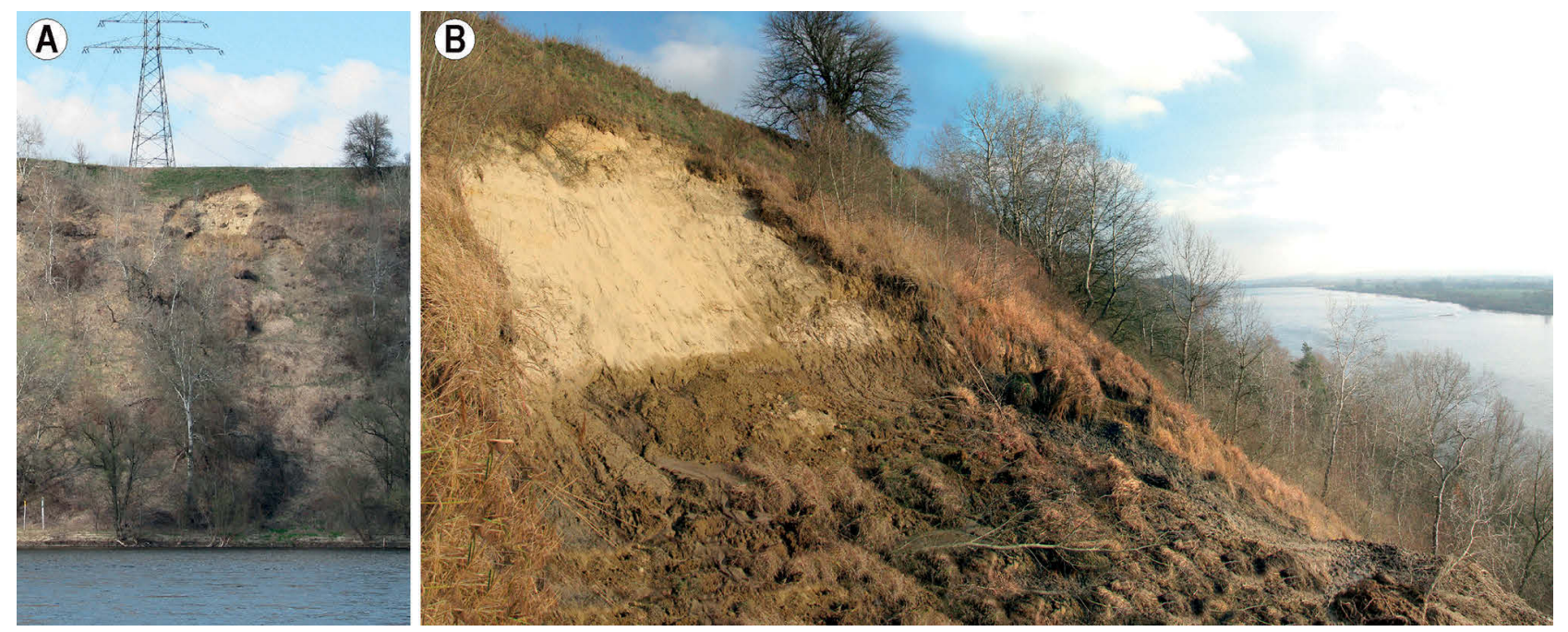

Ryc. 4. Osuwisko w Morsku

A - widok ogólny, B - skarpa główna

Fig. 4. Landslide in Morsk

A - overall view, B - main scarp 

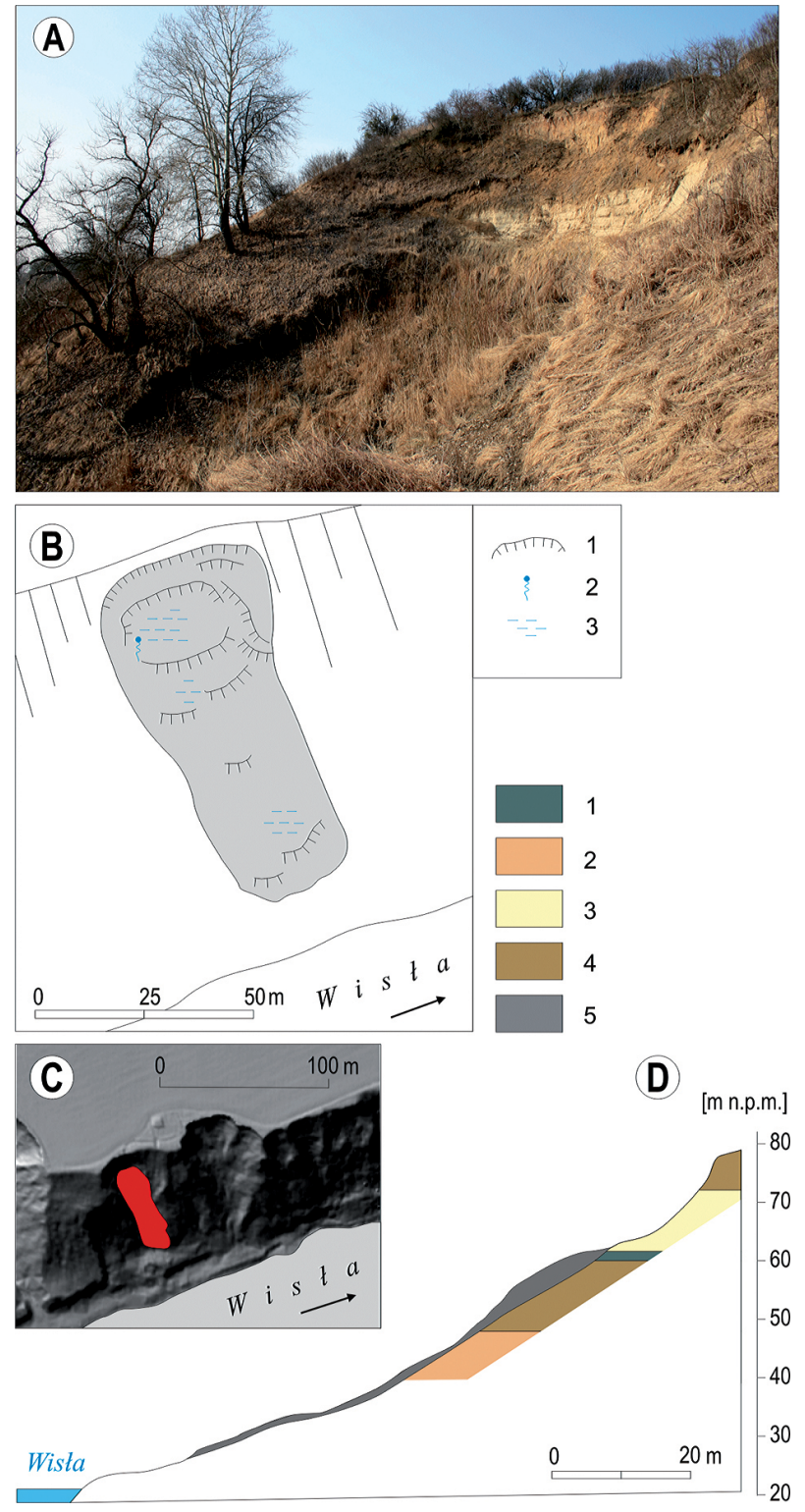

Ryc. 5. Osuwisko w Morsku rozwinięte w obrębie niewielkiego, nieaktywnego wcięcia erozyjnego w górnej części stoku

A - skarpa główna, B - szkic morfologii osuwiska (1 - skarpy, 2 - źródła, 3 - młaki), C - położenie osuwiska w obrębie strefy krawędziowej, D - przekrój geologiczny wzdłuż osi podłużnej osuwiska (1-ił, 2 - mułek, 3 - piasek, 4 - glina, 5 - koluwia, 6 - wiercenia)

Fig. 5. Landslide in Morsk, developed in small, inactive erosion valley, in the upper part of the slope

A - main scarp, B - morphology of the landslide (1 - scarps, 2 - springs, 3 - swamps), $\mathrm{C}$ - location on the escarpment zone, D - geological cross-section along the longitudinal axis of the landslide (1 - clay, 2 - silt, 3 - sand, 4 - till, 5 - colluviums, 6 - boreholes)

ny Wisły świadczy wskaźnik osuwiskowości powierzchni $\left(\mathrm{O}_{\mathrm{p}}\right)$ wynoszący $30 \%$ oraz wskaźnik gęstości osuwisk (G) wynoszący 156 . Są to najwyższe wartości spośród wielu analizowanych przez autora obszarów testowych na odcinku doliny Wisły między Fordonem a Grudziądzem (Tyszkowski 2012c).

Wśród zidentyfikowanych osuwisk w omawianej strefie wyróżniono trzy zasadnicze typy genetyczne. Pierwszy $\mathrm{z}$ nich stanowią formy osuwiskowe inicjowa- ne w górnej części stoku. Ich morfologię przedstawiono na przykładzie dwóch współczesnych osuwisk, które uformowały się w latach 2008 i 2010. Osuwisko zarejestrowane w Morsku powstało w grudniu 2008 r. na stoku o nachyleniu $34^{\circ}$ (ryc. 3, 4). Ma ono 83 m długości i $31 \mathrm{~m}$ szerokości, a skarpa główna znajduje się $4 \mathrm{~m}$ poniżej górnej krawędzi stoku. Materiał pochodzący z niszy osuwiskowej został niemal w całości rozmyty i zakumulowanych w środkowej części stoku. Tam też doszło do powstania niewielkiej skarpy wtórnej o wysokości $2 \mathrm{~m}$. Znaczna część koluwiów nie pozostała na stoku i trafiła bezpośrednio do koryta Wisły.

Kolejne osuwisko, powstałe także w górnej części stoku wskutek epizodycznego wypływu wód gruntowych, różni się od poprzednio omawianego położeniem geomorfologicznym, gdyż ulokowane jest w obrębie niewielkiego, nieaktywnego wcięcia erozyjnego (ryc. 5). Pochodzący z niszy materiał został zdeponowany bezpośrednio poniżej tej niszy i jedynie w niewielkim stopniu uległ rozmyciu i dalszej redepozycji. Epizodyczne pojawianie się wysięków w górnej części stoku, na kontakcie piasków wodonośnych $\mathrm{z}$ utworami słabo przepuszczalnymi, jest zjawiskiem stosunkowo często spotykanym również na sąsiednich odcinkach strefy krawędziowej. Wiele takich miejsc rejestrowanych było podczas kartowania terenowego lub w trakcie analizy zdjęć lotniczych.

Drugi typ osuwisk to formy rozwinięte w dolnej części stoku (ryc. 6). Stanowią one mniej liczną grupę i są jednocześnie starsze w stosunku do wcześniej prezentowanych form. Ich pionowy zasięg obejmuje stok od jego podnóża do rzędnej 30-35 m n.p.m. Osuwiska te rozwinięte są przede wszystkim w obrębie iłów i mułków warwowych, piasków oraz w osadach deluwialnych. W większości mają charakter szerokich zsuwów rotacyjnych. Ich morfologia wskazuje na jednorazowe przemieszczenie, a powierzchnia poślizgu znajduje się na większej głębokości niż w przypadku osuwisk w górnej części stoku i wynosi średnio 2,5 m. Wysokość skarp głównych waha się od 2 do $4 \mathrm{~m}$, średnia długość zbliżona jest do $25 \mathrm{~m}$, a szerokość do około $35 \mathrm{~m}$. Nie spotyka się tu młodych osuwisk, a wiek niemal wszystkich form określono na co najmniej 50 lat. Ich głównym czynnikiem inicjującym jest oddziaływanie rzeki poprzez bezpośrednie podcinanie stoku oraz zmiany w gruncie, głównie w luźnych piaskach i mułkach, pod wpływem wahań wilgotności gruntu i zwierciadła wód podziemnych powiązanych ze zwierciadłem wód Wisły.

Trzecim typem osuwisk są formy poligenetyczne. Należy do nich rozległe osuwisko w Wiągu o powierzchni 2,2 ha, długości $130 \mathrm{~m}$ i szerokości $250 \mathrm{~m}$ (Tyszkowski 2012a) (ryc. 7). Jego budowa geologiczna i wielkość przemieszczeń wskazuje, że powierzchnia poślizgu mogła powstać na głębokości kilkunastu metrów, a przemieszczenie miało charakter głębokiego zsuwu rotacyjnego. Do największych przemieszczeń w jego obrębie dochodziło w trakcie znaczących wezbrań na Wiśle (Tyszkowski 2012b). Ostatnie pomiary wykonane w 2014 r. wskazują, że osuwisko to jest nadal aktywne, a jego ruch jest pulsacyjny. 


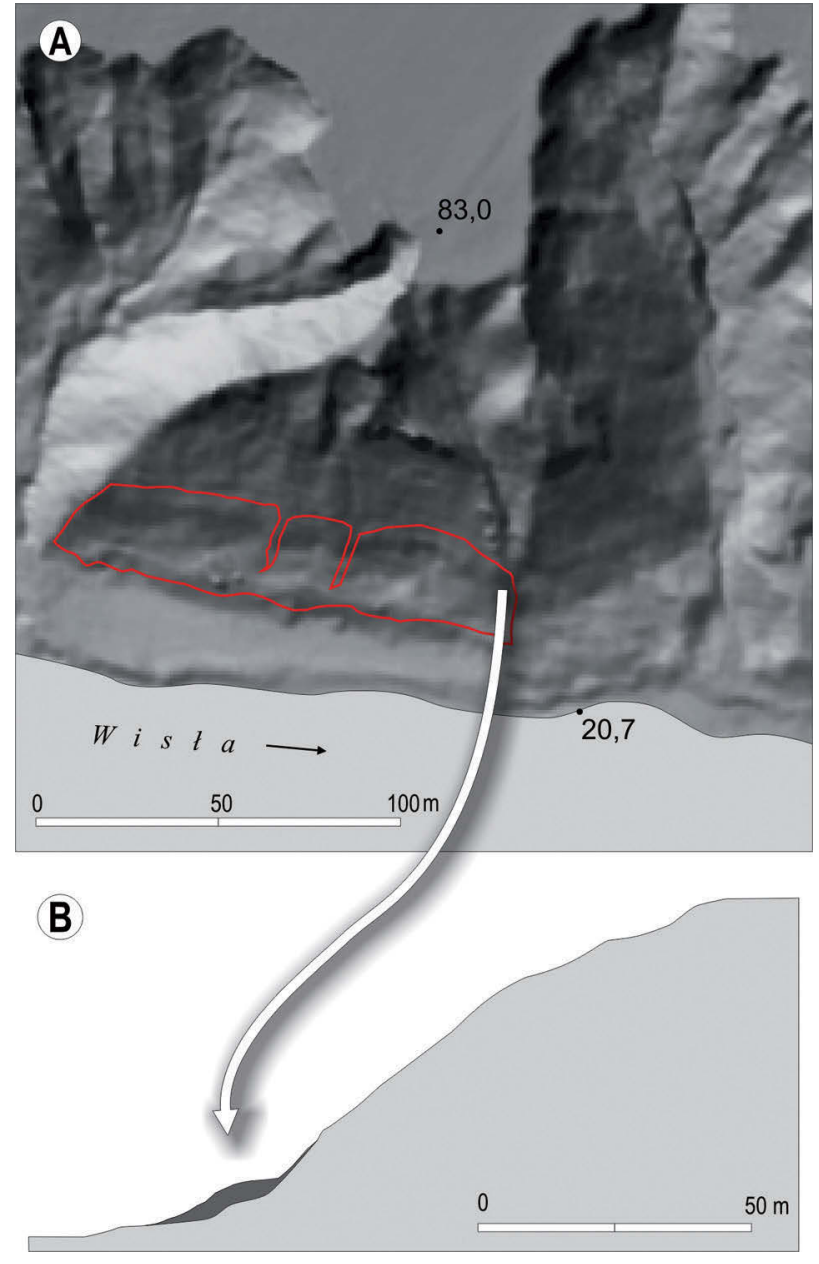

Ryc. 6. Grupa trzech osuwisk rozwiniętych w dolnej części stoku w Wiągu

A - położenie osuwiska w obrębie stoku, B - profil morfologiczny osuwiska północnego

Fig. 6. Group of three landslides developed in the lower part of the slope in Wiagg

A - landslide location on the slope, B - morphological profile of the northern landslide

\section{Dyskusja}

Pod względem mechanicznym do powstania osuwisk prowadzi zachwianie równowagi pomiędzy siłami tarcia i ciężkości. Kluczem do oceny sposobu powstawania i rozwoju tych form jest poznanie czynników aktywizujących. Czynniki te dzielą się na dwie zasadnicze grupy: bierne i aktywne (Zabuski i in. 1999). Uogólniając, można stwierdzić, że czynniki bierne to cechy zbocza niezmienne w krótkim okresie, czyli m.in. budowa geologiczna czy morfologia stoku (kąt nachylenia powierzchni). Za czynniki aktywne uważa się czynniki zewnętrzne oddziałujące na zbocze, w tym opady atmosferyczne oraz podcinanie zboczy.

$\mathrm{Na}$ obszarach górskich, np. w Karpatach, głównym czynnikiem biernym determinującym i różnicującym przestrzenne występowanie osuwisk jest budowa geologiczna, a szczególnie wykształcenie litologiczno-facjalne płaszczowin fliszowych (Zabuski i in. 2009). W przypad-
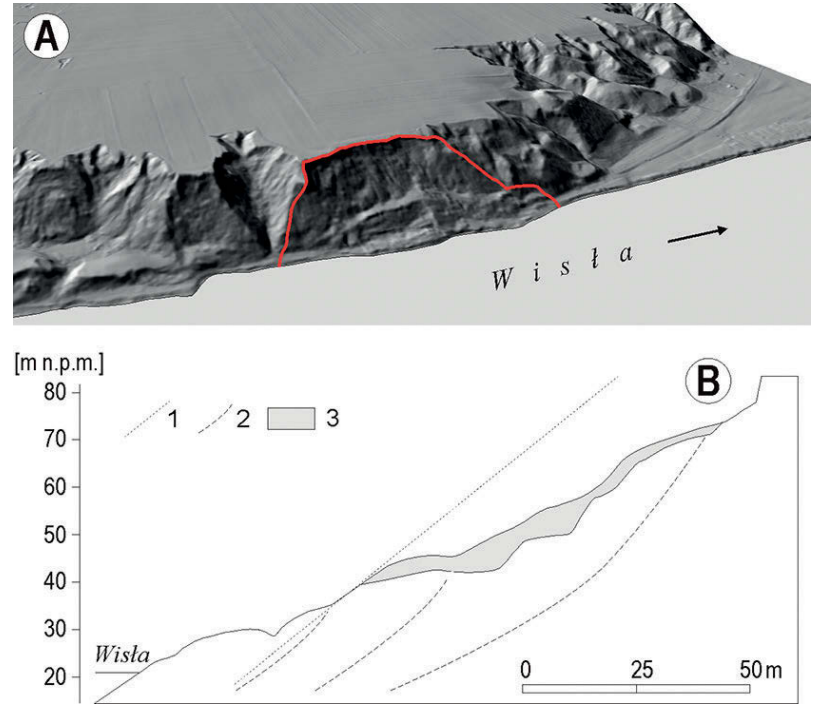

Ryc. 7. Największe z osuwisk w obrębie analizowanego odcinka strefy krawędziowej

A - przedstawione na tle modelu terenu pochodzącego ze skaningu ALS, B - profil morfologiczny osuwiska w Wiągu (Tyszkowski 2012a) (1 zarys zbocza z 1961 r., 2 - przypuszczalne powierzchnie poślizgu, 3 gliniaste koluwia spływowe)

Fig. 7. The biggest landslide in the analyzed escarpment zone A - presented on the background of terrain model from ALS scanning, B - morphological profile of landslide in Wiąg (Tyszkowski 2012a) (1 - slope outline in 1961, 2 - supposed slide surfaces, 3 - colluvial diamicton)

ku analizowanego terenu doliny Wisły układ i charakter warstw geologicznych jest dużo bardziej sprzyjający utrzymaniu stabilności stoku niż na obszarach fliszowych. Pod względem budowy najistotniejsze znaczenie dla aktywizacji osuwisk ma występowanie utworów spoistych, glin i iłów (Tyszkowski 2012a, c, Banach i in. 2013), będących izolacją dla spągu warstw wodonośnych oraz bezpośrednio miejscem wykształcenia powierzchni poślizgu.

Kluczowe znaczenie dla rozwoju osuwisk mają jednak czynniki aktywne. Pierwszym, najbardziej oczywistym dla tego obszaru, jest erozyjne podcinanie stoku przez Wisłę. Proces ten kształtuje rzeźbę już od około 14,5-15 tys. lat, po bifurkacji Wisły, powstaniu przełomu pod Fordonem i wytopieniu brył martwego lodu (Wiśniewski 1993, Weckwerth 2006, Kordowski 2014). Kordowski (2009) podkreśla natomiast dużą dynamikę ramion $\mathrm{w}$ okresie roztokowego funkcjonowania rzeki oraz $\mathrm{w}$ trakcie wezbrań. Wprawdzie oddziaływanie rzeki w ostatnich latach zostało zmniejszone poprzez zabudowę hydrotechniczną, to jednak duże nachylenie stoków sprzyjające rozwojowi ruchów masowych jest efektem oddziaływania głównie tego czynnika. W zbliżonych warunkach geologicznych i klimatycznych proces ten został opisany również przez Banacha (1998) dla brzegów Zbiornika Włocławskiego.

$\mathrm{W}$ przypadku osuwisk inicjowanych $\mathrm{w}$ dolnej części stoku oraz częściowo dla rozległych form obejmujących cały stok istotne znaczenie ma czynnik dynamicznej zmiany zwierciadła wód gruntowych i wyparcia hydraulicznego, którego mechanizm został szerzej scharakteryzowany przez autora na przykładzie osuwiska w Wiągu (Tyszkowski 2012a). Do powstania osuwiska lub zwiększenia dyna- 
miki jego przemieszczeń dojść może w trakcie nagłego obniżenie stanów wody w rzece po znacznych wezbraniach. $\mathrm{Na}$ grunty, których parametry wytrzymałościowe zostały obniżone w wyniku podniesienia poziomu wód gruntowych, zaczynają dodatkowo działać siły parcia hydraulicznego przemieszczającej się w poziomie wody.

W Polsce południowej czynnikiem aktywizującym osuwiska sa obecnie przede wszystkim opady atmosferyczne (Gil, Starkel 1979, Poprawa, Rączkowski 2003, Gorczyca 2004, Rączkowski 2007). Wpływają one również znacząco na rozwój osuwisk nizinnych (Sysak 1961, Banach 1977, 2013, Tyszkowski 2012c). Niemniej zarówno sumy roczne opadów, jak i ich mniejsza intensywność sprawiają, że dużo trudniej je zidentyfikować i określić ich wpływ na rozwój konkretnego osuwiska. Jest to możliwe jedynie w przypadku jednoczesnego aktywowania większej liczby osuwisk na danym terenie. Do sytuacji takich dochodzi stosunkowo rzadko. Jak dotychczas (w ciągu ostatnich 40 lat) dla obszaru Doliny Dolnej Wisły udało się zidentyfikować jedno takie zdarzenie, które nastąpiło w 1980 r. (Tyszkowski 2012b). W przypadku osuwisk występujących między Morskiem a Wiągiem rola opadów atmosferycznych wydaje się jednak nie mieć pierwszorzędnego znaczenia. Dzieje się tak, ponieważ zbocza strefy krawędziowej są stosunkowo krótkie i nie tworzą dużych zlewni powierzchniowych. Jednocześnie znaczne nachylenie stoków nie sprzyja infiltracji, a ich południowa ekspozycja przyśpiesza parowanie, prowadząc do zmniejszenia wilgotności gruntu.

W przypadku osuwisk inicjowanych w górnej części zbocza, obok licznych czynników pośrednich, najważniejsza jest epizodyczna aktywność pierwszego poziomu wód gruntowych na stokach. Aktualnie nawet niewielkie wysięki mogą spowodować powstanie osuwisk, co jest typowe dla osuwisk w Morsku. Wysięki te powstają na kontakcie stropu glin lub iłów oraz piasków bądź mułków. Ich aktywność trwa od kilku miesięcy do kilku lat. Później w większości wysięki te zanikają. W sporadycznych przypadkach wieloletniego trwania wypływów mogą one inicjować powstanie krótkich wcięć erozyjnych. Rola wysięków została również zauważona na stokach doliny Wisły w okolicach Strzelców Dolnych i Trzęsacza, około 35 km na południowy zachód od obszaru badań (Tyszkowski 2012c). Rozwój znajdujących się tam wysięków następował w czasie długich i intensywnych opadów atmosferycznych, czego nie potwierdzono w okolicach Świecia.

Zaliczenie osuwisk zbocza doliny Wisły pomiędzy Morskiem a Wiągiem do form powstałych w strefie bezpośredniego oddziaływania rzeki wynika przede wszystkim z ich położenia w obrębie strefy krawędziowej kształtowanej dawniej i współcześnie przez erozyjną działalność Wisły. Erozja rzeki oraz budowa geologiczna determinuje wystąpienie zespołu biernych czynników osuwiskowych, stanowiących przyczynę pośrednią powstania ruchów masowych.

Uzyskane dla badanego obszaru wysokie wartości wskaźników gęstości osuwisk $(\mathrm{G}=156)$ oraz osuwiskowości powierzchni $\left(\mathrm{O}_{\mathrm{p}}=30 \%\right)$ wynikają ze specyfiki przyjętych do obliczeń założeń. Na przykład dla terenów gór- skich jako powierzchnię odniesienia traktuje się często jednostki morfostrukturalne wyróżnione w oparciu o kryteria budowy geologicznej i rzeźby powierzchni (Zabuski i in. 1999), czy też jednostki administracji terytorialnej. Często przy tym nie uwzględnia się zasięgu teras wysokich (Bober 1979, 1984). W przypadku analizowanego odcinka doliny Wisły autor za powierzchnię odniesienia przyjął stoki strefy krawędziowej jako jedyne tereny, na których osuwiska mogą zaistnieć. Stąd też można je porównywać wyłącznie do obszarów, dla których stosowano podobne kryteria wyznaczania parametrów występowania osuwisk, jak np. dla prawego brzegu Zbiornika Włocławskiego (Banach, Spanila 2000) oraz doliny Wisły w okolicy Fordonu (Tyszkowski 2012c). W pierwszym przypadku określono, że 32\% linii brzegowej stanowią brzegi osuwiskowe. W drugim natomiast wskaźnik osuwiskowości powierzchni wyniósł $\mathrm{O}_{\mathrm{p}}=4 \%$, a gęstości osuwisk $\mathrm{G}=18$. Tam też średnia powierzchnia osuwisk jest niemal dwukrotnie większa niż między Morskiem a Wiągiem i wynosi około $3700 \mathrm{~m}^{2}$. Ze względu na różnice w dokładności materiałów dokumentacji terenowej osuwisk, pochodzących z rejestracji z 1971 i 2004 r., a przedstawionych w niniejszej pracy ich porównanie nie jest możliwe.

\section{Podsumowanie}

Strefa krawędziowa Doliny Dolnej Wisły między Morskiem a Wiągiem należy pod względem geomorfologicznym do specyficznych i stosunkowo rzadko spotykanych obszarów, w których rzeka podcina zbocze doliny przyległej do wysoczyzny. Takie położenie stwarza naturalne predyspozycje do powstawania osuwisk. Badania wskazują na dominację tego procesu we współczesnym kształtowaniu przedstawionego fragmentu zbocza doliny. Obecność osuwisk na badanych stokach jest powszechna. Formy te obejmują $30 \%$ powierzchni stoku.

W przypadku najliczniejszej grupy osuwisk, generowanych w górnej części zbocza, do aktywizacji procesów osuwiskowych dochodzi w wyniku epizodycznej aktywność wód gruntowych pierwszego poziomu wodonośnego i w efekcie ich wypływów na stok. W przypadku pozostałych osuwisk można mówić o formach poligenetycznych, gdyż tworzą się one w rezultacie łącznie działających procesów podcięcia stoku, wahań poziomu wody w rzece oraz aktywności wód gruntowych. Z uwagi na przeprowadzone prace hydrotechniczne, zabezpieczające brzegi przed erozją, duże zdarzenia osuwiskowe modelują rzeźbę dolnej części stoku jedynie w trakcie ekstremalnych wezbrań.

\section{Podziękowania}

Autor pragnie serdecznie podziękować Recenzentom za krytyczne uwagi dotyczące treści artykułu. Badania finansowane są ze środków MNiSW jako projekt badawczy własny nr NN 306086037 oraz w ramach projektu ICLEA (Helmholtz-Virtual Institute). 


\section{Literatura}

Alexandrowicz Z., Margielewski W., 2010. Impact of mass movements on geo- and biodiversity in the Polish Outer (Flysch) Carpathians. Geomorphology 123: 209-304.

Babiński Z., Grześ M., 1995. Monografia hydrologiczna zbiornika stopnia wodnego Włocławek. Zeszyty Instytutu Geografii i Przestrzennego Zagospodarowania Polska Akademia Nauk 30

Banach M., 1977. Rozwój osuwisk na prawym zboczu doliny Wisły między Dobrzyniem a Włocławkiem. Prace Geograficzne 124.

Banach M., 1994. Morfodynamika strefy brzegowej Zbiornika Włocławskiego. Prace Geograficzne 161.

Banach M., 1998. Dynamika brzegów dolnej Wisły. Dokumentacja Geograficzna 9.

Banach M., Kaczmarek H., Tyszkowski S., 2013. Rozwój osuwisk w strefie brzegowej sztucznych zbiorników wodnych na przykładzie osuwiska centralnego w Dobrzyniu nad Wisłą, Zbiornik Włocławski. Przegląd Geograficzny 85(3): 397-415.

Banach M., Spanila T., 2000. Geodynamic evolution of water reservoir banks. Acta Montana IRSM AS CR, seria A, 15: 45-66.

Bober L., 1979. Structural landslides regions in the polish flysh Carpathians and their relation to geology of this mountain range. $\mathrm{W}$ : Superficial mass movements in mountain regions. Proceedings. $1^{\text {st }}$ Polish-Italian Seminar, Szymbark. Instytut Meteorologii i Gospodarki Wodnej, Warszawa: 18-34.

Bober L., 1984. Rejony osuwiskowe w polskich Karpatach fliszowych i ich związek z budową geologiczną regionu. Biuletyn Instytutu Geologicznego 340(23).

Chmielowska U., 1997. Mapa hydrogeologiczna Polski, arkusz Rudnik (244), 1:50 000. Państwowy Instytut Geologiczny, Warszawa.

Churski Z., 1993. Reżim dolnej Wisły. W: Z. Churski (red.), Uwarunkowania przyrodnicze i społeczno-ekonomiczne zagospodarowania dolnej Wisły. Instytut Geografii, Uniwersytet Mikołaja Kopernika, Toruń: 51-64.

Florek W., Zwoliński Z., Andrzejewski L., Kostrzewski A., Smolska E., Szmańda J., 2008. Współczesne procesy kształtujące rzeźbę dolin rzecznych. W: L. Starkel, A. Kostrzewski, A. Kotarba, K. Krzemień (red.), Współczesne przemiany rzeźby Polski. Instytut Geografii i Gospodarki Przestrzennej, Uniwersytet Jagielloński, Kraków: 292-304.

Galon R., 1934. Dolina dolnej Wisły, jej kształt i rozwój na tle budowy dolnego Powiśla. Badania Geograficzne nad Polską Północno-Zachodnią 12/13.

Gil E., Starkel L., 1979. Long-term extreme rainfalls and their role in the modelling of flysh slopes. Studia Geomorphologica Carpatho-Balcanica 13: 207-220.

Glazer Z., 1998. Naukowo-techniczne problemy Skarpy Płockiej. Przemieszczenia Skarpy Płockiej. Instytut Techniki Budowlanej, Warszawa: $41-48$.

Gorczyca E., 2004. Przekształcenie stoków fliszowych przez ruchy masowe podczas katastrofalnych opadów (dorzecze Łososiny). Wydawnictwo Uniwersytetu Jagiellońskiego, Kraków.

Grabowski D., Marciniec P., Mrozek T., Neścieruk P., Raczzkowski W., Wójcik A., Zimnal Z., 2008. Instrukcja opracowania mapy osuwisk i terenów zagrożonych ruchami masowymi w skali 1:10 000. Państwowy Instytut Geologiczny, Warszawa.

Grobelska H., 2006. Ewolucja strefy brzegowej zbiornika pakoskiego (Pojezierze Gnieźnieńskie). Prace Geograficzne 205.

Habel M., Tyszkowski S., Skowroński T., 2008. Morphodynamic analysis of lower Vistula valley using GPS, sonar and aerial photography. Annals of Geomatics 1(6): 91-100.

Kaczmarek H. 2010a. Analiza zdjęć lotniczych oraz wyników pomiarów geodezyjnych w badaniach dynamiki strefy brzegowej sztucznych zbiorników wodnych - zbiornik Jeziorsko, rzeka Warta. Landform Analysis 13: 19-26.

Kaczmarek H., 2010b. Development of the shore zone of the Jeziorsko Reservoir (the Warta River, Central Poland). Geomorphologia Slovaca et Bohemica 10(1): 16-24

Kordowski J., 2009. On the Lower Vistula valley development in the light of geomorphological and sedimentological investigations. Polish Geological Institute Special Papers 25: 21-36.
Kordowski J., 2014. Rola brył martwego lodu w morfogenezie Kotliny Grudziądzkiej i Basenu Świeckiego - formy rzeźby i osady. Landform Analysis 25.

Kordowski J., Tyszkowski S., 2008. Wstępne wyniki badań nad procesami osuwiskowymi w wąwozie Czerwonej Wody koło Świecia. Landform Analysis 9: 59-62.

Kotarba A., 1986. Rola osuwisk w modelowaniu rzeźby beskidzkiej i pogórskiej. Przegląd Geograficzny 58(1-2): 119-129.

Kühn A., 1981. Wpływ czynników geologicznych na prognozę stateczności skarpy wiślanej w Dobrzyniu. W: K. Thiel (red.), Stateczność skarpy wiślanej i metody jej zabezpieczania na przykładzie Płocka i Dobrzynia. Towarzystwo Naukowe Płockie: 74-82.

Kühn A., Miłoszewska W., 1971. Katalog osuwisk - województwo bydgoskie. Warszawa.

Mojski J.E., 1982. Środowisko przyrodnicze. Geologiczne warunki powstania i rozwoju Doliny Dolnej Wisły. W: B. Augustowski (red.), Dolina Dolnej Wisły. Wrocław, Warszawa, Kraków, Gdańsk, Łódź: $19-60$.

PN-B-04452:2002, 2002. Geotechnika. Badania polowe. Polski Komitet Normalizacji.

Poprawa D., Rączkowski W., 2003. Osuwiska Karpat. Przegląd Geologiczny 51(8): 685-692.

Rączkowski W., 2007. Landslide hazard in the Polish Flysch Carpathians. Studia Geomorphologica Carpatho-Balcanica 41: 61-75.

Rejestracja, 2004. Rejestracja i inwentaryzacja naturalnych zagrożeń geologicznych na terenie całego kraju (ze szczególnym uwzględnieniem osuwisk oraz innych zjawisk geodynamicznych). Online: 1.05.2014 - http://geozagrozenia.pgi.gov.pl/.

Starkel L., 1960. Rozwój rzeźby Karpat fliszowych w holocenie. Prace Geograficzne 22.

Sysak J., 1961. Próba wyznaczenia zależności między prędkością ruchu osuwiska a natężeniem opadów atmosferycznych. Politechnika Warszawska.

Tyszkowski S., 2008. Badania rozwoju osuwisk w rejonie Świecia, na podstawie materiałów fotogrametrycznych. Landform Analysis 9: 385-389.

Tyszkowski S., 2009. Zjawiska i formy osuwiskowe w wąwozie Czerwonej Wody (Wysoczyzna Świecka) - wybrane problemy. Funkcjonowanie środowiska przyrodniczego w okresie przemian gospodarczych w Polsce. Biuletyn Monitoringu Środowiska, Szymbark: 316-321.

Tyszkowski S., 2012a. Rekonstrukcja dynamiki oraz próba określenia czynników inicjujących ruchy osuwiskowe we Wiagu (Dolina Dolnej Wisły). Prace i Studia Geogr., Wydział Geografii i Studiów Regionalnych, Uniwersytet Warszawski 49: 211-219.

Tyszkowski S., 2012b. Rola ruchów osuwiskowych w rozwoju strefy krawędziowej wybranych odcinków Doliny Dolnej Wisły. MS, Instytut Geografii i Przestrzennego Zagospodarowania, Polska Akademia Nauk.

Tyszkowski S., 2012c. Rozmieszczenie i skala aktywności współczesnych osuwisk w dolinie dolnej Wisły na odcinku między Fordonem a Kozielcem (Polska północna) - wstępne wyniki badań. Landform Analysis 20: 91-97.

Weckwerth P., 2006. Problem bifurkacji Wisły pod Fordonem (Bydgoszcz) na tle ewolucji Kotliny Toruńskiej pod koniec plenivistulianu. Przegląd Geograficzny 78(1): 47-68.

Wiśniewski E., 1993. Morfogeneza doliny dolnej Wisły. W: Z. Churski (red.), Uwarunkowania przyrodnicze i społeczno-ekonomiczne zagospodarowania dolnej Wisły. Instytut Geografii, Uniwersytet Mikołaja Kopernika, Toruń: 35-50.

Wójcik G., Marciniak K., 1993. Opady atmosferyczne w regionie dolnej Wisły w okresie 1951-1980. W: Z. Churski (red.), Uwarunkowania przyrodnicze i społeczno-ekonomiczne zagospodarowania dolnej Wisły. Instytut Geografii, Uniwersytet Mikołaja Kopernika, Toruń: 107-122.

WP/WLI, 1993. The International Geotechnical Societes (UNESCO) Working Party for World Landslide Inventory. Multilingual Landslide Glossary. The Canadian Geotechnical Society, BiTech Publishers LTD, Richmond BC, Canada. 
Wysokiński L., 1998. Zabezpieczenie Skarpy Płockiej i jej uwarunkowania. Przemieszczenia Skarpy Płockiej. Instytut Techniki Budowlanej, Warszawa: 95-143.

Wysota W., 2002. Stratygrafia i środowiska sedymentacji zlodowacenia wisły w południowej części dolnego Powiśla. Wydawnictwo Naukowe Uniwersytetu Mikołaja Kopernika, Torun.

Zabuski L., Thiel K., Bober L., 1999. Osuwiska we fliszu Karpat polskich: geologia, modelowanie, obliczenia stateczności. Wydawnictwo Instytutu Budownictwa Wodnego, Polska Akademia Nauk, Gdańsk.
Zabuski L., Wójcik A., Gil E., Mrozek T., Rączkowski W., 2009. Landslide processes in a flysch massif - case study of the Kawiory landslide, Beskid Niski Mts. (Carpathians, Poland). Geological Quarterly 53(3): 317-332.

Zambrzycka M., 2002. Mapa hydrogeologiczna Polski, arkusz Chełmno (243), 1:50 000. Państwowy Instytut Geologiczny, Warszawa.

Ziętara T., 1988. Landslide areas in the Polish Flysh Carpathians. Folia Geographica, Geographica-Physica 20: 21-67. 